\title{
Climate change and altitudinal variation in sexual size dimorphism of arctic wolf spiders
}

\author{
Toke Thomas Høye ${ }^{1, *}$, Jörg U. Hammel ${ }^{2}$ \\ ${ }^{1}$ Department of Wildlife Ecology and Biodiversity, National Environmental Research Institute, Aarhus University, \\ Grenåvej 14, 8410 Rønde, Denmark \\ ${ }^{2}$ Institute of Systematic Zoology and Evolutionary Biology with Phyletic Museum, Friedrich-Schiller-University Jena, \\ Erbertstr. 1, 07743 Jena, Germany
}

\begin{abstract}
Climate change is advancing the onset of the growing season, and this is happening at a particularly fast rate in the Arctic. Although this has recently been shown to affect the sexual size dimorphism (SSD) of a wolf spider species through time, it remains to be shown whether spatial variation in the physical environment is similarly affecting SSD. We studied altitudinal variation in adult body size of male and female wolf spiders on Disko Island, West Greenland. Two species exhibited female-biased SSD (measured by carapace width) at sea level but not at higher altitudes. Males and females of a third species were of equal size at both altitudes, and the 2 remaining species found on Disko Island were only present at 1 low altitude site each. Altitudinal variation in SSD is probably a result of sex differences in body size response to shorter growing seasons with altitude. Our results suggest that climate change may result in increased SSD. Constraints on body size may increase with altitude, and expanding growing seasons due to climate change may predominantly affect SSD at higher altitudes. Such intra-specific effects of climate may be widespread and suggest that further research in this topic is needed.
\end{abstract}

KEY WORDS: Body size - Carapace width $\cdot$ Climate impacts $\cdot$ Intra-specific variation $\cdot$ Lycosidae

\section{INTRODUCTION}

The Arctic is currently warming at 2 to 3 times the global average, resulting in rapidly expanding growing seasons (Trenberth et al. 2007) and advancements of species phenology (Høye et al. 2007). A better understanding of the ecological consequences of these changes in the Arctic environment is urgently needed (Callaghan et al. 2005, Post et al. 2009). Differential phenological responses of consumers and resources can lead to trophic mismatch (Post \& Forchhammer 2008), but a longer growing season also leaves more time for offspring development, which could increase reproductive success (Meltofte et al. 2008). While such inter-specific differences in climate responses are welldocumented, the role of intra-specific variation in climate responses is receiving little attention. At lower latitudes, intra-specific differences in phenotypic responses to climate have been documented in amphib- ians (Tryjanowski et al. 2006), and sex-specific densitydependence appears to affect population dynamics (Mysterud et al. 2002). Theoretical advances also suggest that individual variation may be particularly important in fluctuating environments (Tuljapurkar et al. 2009).

Body size is strongly related to fitness (Roff 1992), and coinciding spatial clines in body size and temperature are particularly evident in ectotherms (Karl \& Fischer 2008). Males are generally larger than females in endotherms (Isaac 2005), while female-biased sexual size dimorphism (SSD) predominates in ectotherms (Teder \& Tammaru 2005). Recently, latitudinal variation in body size has also been shown to differ among the sexes (Blanckenhorn et al. 2006, Howes \& Lougheed 2007). If such large-scale geographic variation arises primarily in response to changes in environmental conditions such as temperature, altitudinal variation in SSD could also be expected (Stillwell \& Fox 2007). 
Recent evidence from the Arctic has demonstrated that male and female body size of the wolf spider Pardosa glacialis responds differently to inter-annual variation in the timing of spring snowmelt (Høye et al. 2009). The ongoing expansion of the growing season and concurrent shifts in arthropod phenology in the Arctic (Høye \& Forchhammer 2008) is amplifying SSD in this species. These results suggest that spatial variation in growing season length, readily observable along altitudinal gradients, may also affect SSD (Chown \& Klok 2003). Here, we tested this prediction by investigating sex differences in adult body size at low and high altitude in 3 species of wolf spiders inhabiting the rapidly changing Arctic environment. In addition, we compared the magnitude of the temporal variation in body size reported earlier (Høye et al. 2009) to the spatial variation observed at different altitudes of 1 of the 3 species ( $P$. glacialis) to discuss likely future responses of the sexes of this species at low versus high altitude.

\section{MATERIALS AND METHODS}

The study was carried out on Disko Island, West Greenland, in 2004 in an area with mountains rising to $800 \mathrm{~m}$ above sea level (a.s.l.). Five spider species of the family Lycosidae (wolf spiders) are found on Disko Island: Pardosa glacialis (Thorell, 1872), P. groenlandica (Thorell, 1872), P. furcifera (Thorell, 1875), P. hyperborea (Thorell, 1872) and Arctosa insignita (Thorell, 1872), and it is the most northerly location in West Greenland for the latter 3 species (Larsen \& Scharff 2003, Hammel \& Nickel 2008). In order to cover a wide selection of habitats, we established sampling locations in 3 different localities: Engelskmandshavn (E), Arktisk Station (S) and Lyngmarksfjeld (L). At each sampling location (Fig. 1), pitfall traps (55 mm radius, $100 \mathrm{~mm}$ deep, filled with water and a few drops of detergent) were placed in pairs, with the second trap placed 6 to $7 \mathrm{~m}$ away from the first (see Hammel 2005 for detailed information). Traps were installed after snowmelt in June and emptied once a week until the sampling ended in early August. Subsequently, species identification and sex determination of adult wolf spiders was done in the laboratory.

We measured the width of the carapace on all adult specimens. The width of the carapace has previously been identified as the most generally useful measure to identify body size variation in wolf spiders (Hagstrum 1971, Pickavance 2001). Digital images were taken through a dissecting microscope using a Nikon Coolpix 990 digital camera. Subsequently, the measurements were obtained using the software ImageJ (Rasband 2008). We divided the sampling locations into 2 groups depending on altitude (below and above

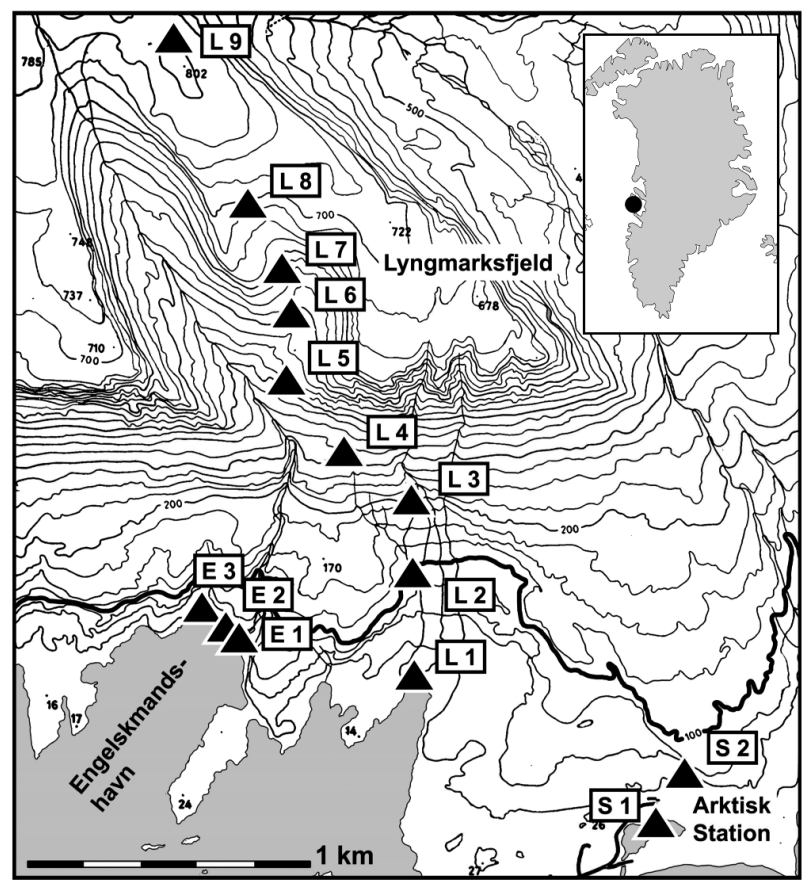

Fig. 1. Disko Island, showing the location of the pitfall traps $(\boldsymbol{\Delta})$ around Arktisk Station (S1, S2), in the Engelskmandshavn area (E1-E3) and along the altitudinal transect at Lyngmarksfjeld (L1-L9). The contour line at $100 \mathrm{~m}$ a.s.l. is highlighted in bold, and the location of the study area is indicated on the inset map of Greenland

$100 \mathrm{~m}$ a.s.l.) and tested for differences in carapace width between the sexes, altitude groups and their interaction using linear mixed models with locality $(\mathrm{E}$, $\mathrm{S}$ or $\mathrm{L}$ ) as random factor to account for spatial variation. We also used regression models to identify significant relationships between carapace width and altitude within each sex for each species.

\section{RESULTS}

The sampling resulted in the collection of 538 adult wolf spider specimens from a total of 69 trap days. Specimens of Pardosa furcifera $(\mathrm{n}=99)$ and P. hyperborea $(\mathrm{n}=1)$ were only found at 1 sampling site each and were therefore omitted from analyses of altitudinal variation. Due to small sample sizes, we pooled specimens from sampling locations E1, E2, E3, L1, S1 and S2 in the low altitude group ( 0 to $100 \mathrm{~m}$ a.s.l.) and specimens from sampling locations L2 to L9 (100 to $800 \mathrm{~m}$ a.s.l.) in the high altitude group (Table 1). To facilitate interpretation of the differences in capture numbers among sampling sites and to add to the sparse knowledge of habitat selection in arctic wolf spiders, a vegetation description (Appendix 1) and capture numbers of 
Table 1. Number of adult specimens of each sex of 5 species of wolf spiders caught in pitfall traps presented for each sampling site individually as well as for sampling sites at low (0 to $100 \mathrm{~m}$ a.s.l.) and high (100 to $800 \mathrm{~m}$ a.s.l.) altitude on Disko Island, West Greenland. The low altitude group includes the sampling locations E1, E2, E3, L1, S1 and S2. The high altitude group includes the sampling locations L2 to L9

\begin{tabular}{|c|c|c|c|c|c|c|c|c|c|c|c|c|c|c|c|c|c|c|}
\hline \multirow[b]{2}{*}{ Species } & \multirow[b]{2}{*}{ Sex } & \multirow[b]{2}{*}{ S1 } & \multirow[b]{2}{*}{$\mathrm{S} 2$} & \multirow[b]{2}{*}{ E1 } & \multirow[b]{2}{*}{ E2 } & \multirow[b]{2}{*}{ E3 } & \multicolumn{3}{|c|}{ - Sampling site } & \multirow[b]{2}{*}{ L4 } & \multirow[b]{2}{*}{ L5 } & \multirow[b]{2}{*}{ L6 } & \multirow[b]{2}{*}{ L7 } & \multirow[b]{2}{*}{ L8 } & \multirow[b]{2}{*}{ L9 } & \multicolumn{3}{|c|}{ Altitude group } \\
\hline & & & & & & & L1 & L2 & L3 & & & & & & & Low & High & Total \\
\hline Arctosa insignita & 우 & & 1 & & & 5 & 8 & 3 & & & & & & & & 14 & 3 & 17 \\
\hline \multirow[t]{2}{*}{ Pardosa furcifera } & @ & & & & & & 33 & & & & & & & & & 33 & 0 & 33 \\
\hline & $0^{4}$ & & & & & & 66 & & & & & & & & & 66 & 0 & 66 \\
\hline P. glacialis & ㅇ & 3 & 14 & & & 48 & 1 & 8 & 12 & 4 & 11 & 5 & & & & 66 & 40 & 106 \\
\hline P. groenlandica & $0^{11}$ & 1 & & 15 & 9 & 27 & 9 & 1 & 6 & 15 & 8 & 17 & 2 & 3 & & 61 & 52 & 113 \\
\hline \multirow[t]{2}{*}{ P. hyperborea } & q & & & & & & & & & & & & & & & 0 & 0 & 0 \\
\hline & $0^{1}$ & & & & & & & 1 & & & & & & & & 0 & 1 & 1 \\
\hline Total & & 18 & 35 & 24 & 33 & 97 & 147 & 33 & 46 & 42 & 24 & 31 & 4 & 3 & 1 & 354 & 184 & 538 \\
\hline
\end{tabular}

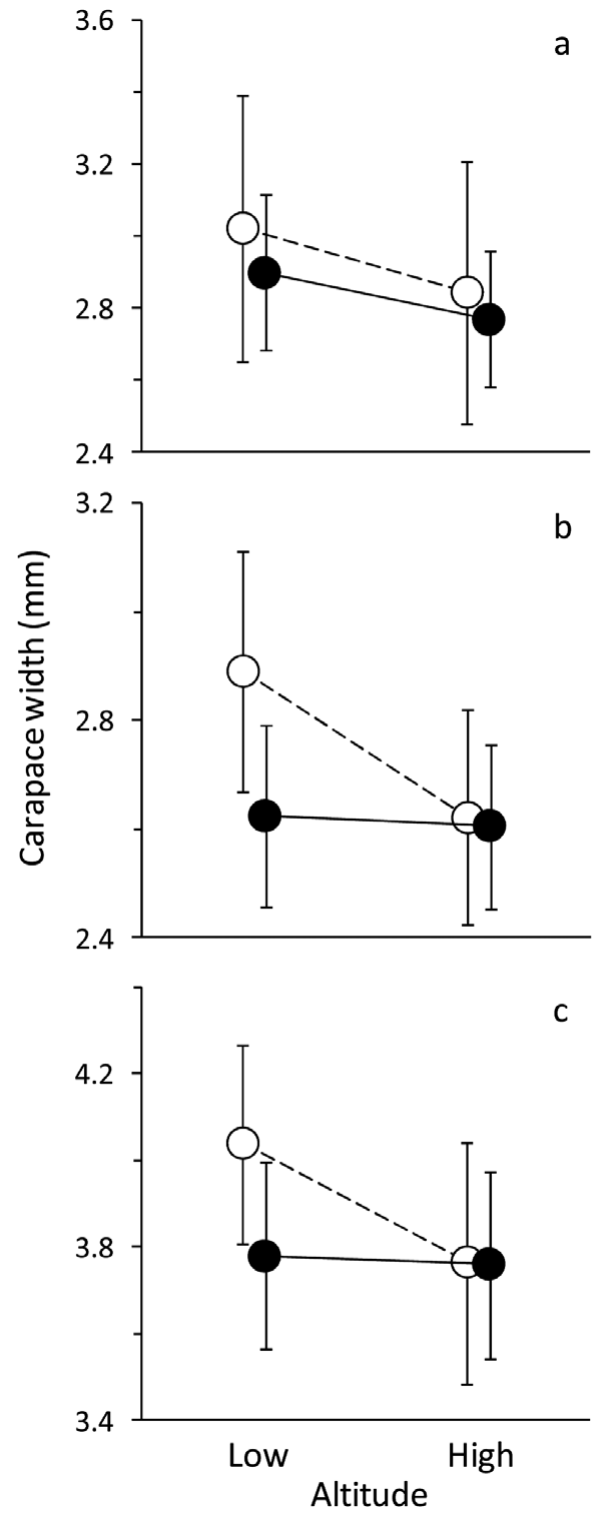

other arthropods at each site is provided (see Table S1 in the supplement at www.int-res.com/articles/suppl/ c041p259_app.pdf). The width of the carapace was larger in females than in males in all 3 species at both low and high altitude (Fig. 2). Based on the linear mixed models for each species, we found no significant effects of sex and altitude on the body size (carapace width) of Arctosa insignita. However, in P. glacialis and P. groenlandica, there was a significant positive interaction between sex and altitude, indicating that the difference in body size between males and females is larger at low than at high altitude (Table 2). Subsequent restriction of the sample to each altitudinal group revealed that female body size was significantly larger than male body size in $P$. glacialis $\left(F_{1,103}=20.64, \mathrm{p}<\right.$ $0.0001)$ and $P$. groenlandica $\left(F_{1,95}=30.74, \mathrm{p}<0.0001\right)$, but not in $A$. insignita $\left(F_{1,49}=2.15, \mathrm{p}=0.15\right)$ at low altitude, whereas at high altitude, body size did not differ significantly between the sexes in any of the 3 species (A. insignita: $F_{1,4}=0.1, \mathrm{p}=0.77 ;$ P. glacialis: $F_{1,108}=$ $0.25, \mathrm{p}=0.61$; and $P$. groenlandica: $F_{1,65}=0.01, \mathrm{p}=$ 0.94). Moving the sampling location L2 (110 $\mathrm{m}$ a.s.l.) from the high altitude group to the low altitude group did not alter the significance level of the F-tests. Regression analyses revealed significant relationships between carapace width $(\mathrm{mm})$ and altitude $(\mathrm{m})$ in females (slope $=-0.00068, \mathrm{n}=106, \mathrm{p}<0.0001, \mathrm{r}^{2}=0.20$ ), but not

Fig. 2. Body size variation in relation to altitude in (a) Arctosa insignita, (b) Pardosa glacialis, and (c) P. groenlandica at Disko Island, West Greenland. Size was measured as the width of the carapace $(\mathrm{mm})$ and the mean $( \pm 1 \mathrm{SD})$, given for females (open dots) and males (filled dots) at low (0 to $100 \mathrm{~m}$ a.s.l.) and high (100 to $800 \mathrm{~m}$ a.s.l.) altitude. The low altitude group includes the sampling locations E1, E2, E3, L1, $\mathrm{S} 1$ and S2. The high altitude group includes the sampling locations L2 to L9 
Table 2. Effects of sex and altitude on the size (carapace width in mm) of 3 species of wolf spiders on Disko Island, West Greenland. Parameter estimates and $\mathrm{p}$ values are given for final reduced linear mixed models and non-significant parameters are indicated by a dash. The value given for the parameter sex is for the female category, and the value given for the parameter altitude is for the low altitude category. In Pardosa glacialis, the model included locality (Engelskmandshavn, Arktisk Station, or Lyngmarksfjeld) as a random factor

\begin{tabular}{|c|c|c|c|c|c|c|c|c|}
\hline \multirow[b]{2}{*}{ Species } & \multicolumn{2}{|c|}{$\longrightarrow$ Intercept } & \multicolumn{2}{|c|}{$\longrightarrow$ Sex } & \multicolumn{2}{|c|}{- Altitude -} & \multicolumn{2}{|c|}{ Sex $\times$ altitude } \\
\hline & Parameter & $\mathrm{p}$ & Parameter & $\mathrm{p}$ & Parameter & $\mathrm{p}$ & Parameter & $\mathrm{p}$ \\
\hline Arctosa insignita & 2.92 & $<0.0001$ & - & - & - & - & - & - \\
\hline P. glacialis & 2.59 & 0.0009 & 0.0169 & 0.0001 & 0.0749 & 0.03 & 0.173 & 0.0013 \\
\hline P. groenlandica & 3.76 & $<0.0001$ & 0.0049 & 0.0015 & 0.0204 & 0.0004 & 0.253 & 0.0022 \\
\hline
\end{tabular}

in males of $P$. glacialis (slope $=-0.00009, \mathrm{n}=111, \mathrm{p}=$ 0.39 ) and similarly for females (slope $=-0.00050, \mathrm{n}=51$, $\mathrm{p}=0.0028, \mathrm{r}^{2}=0.17$ ), but not in males (slope $=-0.00001$, $\mathrm{n}=113, \mathrm{p}=0.91$ ) of $P$. groenlandica. In A. insignita, neither females (slope $=-0.0018, \mathrm{n}=17, \mathrm{p}=0.42$ ), nor males (slope $=-0.00079, \mathrm{n}=40, \mathrm{p}=0.39$ ) showed a significant relationship. However, all 6 regression coefficients were negative, thus indicating a consistent decrease in body size with altitude.

\section{DISCUSSION}

In spiders, SSD is believed to arise primarily as a result of fecundity selection on females (Prenter et al. 1999). Egg mass production is likely to be limited by female size, and hence larger females may produce more and/or larger eggs (Simpson 1993, 1995). In contrast, reproductive success in males may be more dependent on the timing of their final moult than on adult body size (Uhl et al. 2004), because early maturing males are likely to mate with more females than late moulting males in the highly seasonal arctic environment (Vertainen et al. 2000). Growing seasons generally become shorter with altitude due to the environmental lapse rate (rate of decrease of temperature with altitude). Hence, the pattern of altitudinal variation in SSD we document here is likely to result from sexspecific growth strategies (Uhl et al. 2004). Female body size may be more sensitive to the altitudinal constraints on growth than male body size, resulting in smaller growth increments during moults (Blanckenhorn et al. 2007) or fewer moults (Esperk et al. 2007) in females at higher altitudes relative to females at low altitude. The differences in altitudinal variation in SSD among the 3 species studied could indicate differences in sex-specific growth strategies among the species. However, we cannot rule out that our limited sample size for Arctosa insignita in particular plays a role in the lack of response in females of this species. The differences in the ecology of these species are poorly known, and attempts to attribute differences in SSD response to the life history of the species would be premature.

While spatial body size clines are widely documented (Chown \& Klok 2003, Millien et al. 2006), there is little evidence of small-scale spatial variation in SSD within species. The altitudinal variation in SSD of wolf spiders documented here corroborates recent documentation of temporal variation in SSD in Pardosa glacialis from the High Arctic (Høye et al. 2009). Temporal variation in SSD was explained by variation in the onset of the growing season and may also explain the altitudinal variation in SSD reported here. Time for development and growth rather than temperature per se may be the underlying driver of both spatial and temporal variation in arctic wolf spiders, but further studies are needed to confirm this. According to our results, body sizes of both sexes are affected by environmental constraints, but the response is much stronger in females than in males both temporally and spatially. Given the scarcity of studies on this topic, environmental effects on SSD could be much more widespread than previously believed, both taxonomically and geographically (Stillwell \& Fox 2007). Average female body size of $P$. glacialis at low altitude was about $10 \%$ larger than at high altitude in this study. The corresponding size increase from the smallest to the largest cohort of our previous study from Zackenberg, north-east Greenland ( $5^{\circ}$ latitude farther north) was about $8 \%$, but the mean size of females at low altitude in the current study was $6 \%$ larger than the largest cohort from Zackenberg (Høye et al. 2009). This supports the conclusion that a longer growing season leads to larger females at least in this species.

We sampled specimens from multiple locations at both low and high altitude to maximise sample size of all species of wolf spiders present in the study area. This could have introduced body size variation between samples not related to altitude. While habitat differences may cause variation in growing condition and body size of arctic spiders, our previous work on Pardosa glacialis from Greenland suggested that growing season length was far more important for 
body size than habitat differences (Høye et al. 2009). Also, in 9 of 11 cases, average body size of females was larger than average body size of males for all species at all low altitude sites where both sexes of a species were caught. The 2 exceptions (S1 for P. glacialis and E3 for $P$. groenlandica) both had small sample sizes, and the consistency of the pattern suggests that our results are not sensitive to the sampling procedure. However, future studies could consider how SSD is affected by the interaction between habitat composition and climate.

Both sexual and nonsexual cannibalism is common in spiders and may be a significant foraging behaviour among wolf spiders (Wise 2006). The frequency of sexual cannibalism increases with SSD in spiders (Wilder \& Rypstra 2008b). We found the largest SSD at low altitude in Pardosa glacialis. Compared to experimental results in another wolf spider species (Hogna helluo), the body size difference between males and females observed in our study could indeed result in frequent sexual cannibalism (Wilder \& Rypstra 2008a). Climate change may shift the body size of wolf spiders, and being top predators in arctic invertebrate communities, this could induce important feed-backs on the structure and dynamics of populations and communities (De Roos et al. 2003, Lensing \& Wise 2006). Also, altitudinal range shifts may invoke changes if sexes and species differ in their body size response to changes in resource availability (Chown \& Klok 2003). Efforts to predict ecosystem responses to climate change may benefit from further attention to such intra-specific variation in responses as documented here.

Spatial variation in SSD can arise either through local adaptation or phenotypic plasticity (Stillwell \& Fox 2009). While there is no evidence to support which of these mechanisms are most important in describing our results, we have previously demonstrated considerable inter-annual variation from the same localities, which could indicate an important role of phenotypic plasticity. Geographic variation in SSD of spiders (Fernández-Montraveta \& Moya-Laraño 2007) and other ectotherm species (Schäuble 2004, Stillwell et al. 2010) also appears to be generated by sex-specific phenotypic plasticity in body size. If phenotypic plasticity is the dominating mechanism, it could suggest that further relaxation of developmental constraints through climate-induced expansion of the growing season may predominantly affect body size of wolf spiders at high altitude.

Acknowledgements. We thank H.D. Görtz for financial and material support of the field work and N. Scharff, J. Böcher and S. Larsen for insights on the spider fauna of Greenland. I. K. Petersen kindly prepared the map of Greenland. J.U.H. received funding from the Landesstiftung Baden-Württemberg. Comments by $\mathrm{S}$. Toft and 4 anonymous referees are greatly appreciated.

\section{LITERATURE CITED}

Blanckenhorn WU, Stillwell RC, Young KA, Fox CW, Ashton KG (2006) When Rensch meets Bergmann: Does sexual size dimorphism change systematically with latitude? Evolution 60:2004-2011

Blanckenhorn WU, Dixon AFG, Fairbairn DJ, Foellmer MW and others (2007) Proximate causes of Rensch's rule: Does sexual size dimorphism in arthropods result from sex differences in development time? Am Nat 169:245-257

Callaghan TV, Chapin FS III, Chernov Y, Christensen TR and others (2005) Arctic tundra and polar desert ecosystems. In: Symon C, Arris L, Heal B (eds) Arctic climate impact assessment. Cambridge University Press, New York, NY, p 243-352

Chown SL, Klok CJ (2003) Altitudinal body size clines: latitudinal effects associated with changing seasonality. Ecography 26:445-455

De Roos AM, Persson L, McCauley E (2003) The influence of size-dependent life-history traits on the structure and dynamics of populations and communities. Ecol Lett 6: 473-487

Esperk T, Tammaru T, Nylin S, Teder T (2007) Achieving high sexual size dimorphism in insects: females add instars. Ecol Entomol 32:243-256

Fernández-Montraveta C, Moya-Laraño J (2007) Sex-specific plasticity of growth and maturation size in a spider: implications for sexual size dimorphism. J Evol Biol 20:1689-1699

Hagstrum DW (1971) Carapace width as a tool for evaluating the rate of development of spiders in the laboratory and the field. Ann Entomol Soc Am 64:757-760

Hammel J (2005) Ökologie und Phylogenie grönländischer Wolfsspinnen (Lycosidae, Araneae). Dipl. thesis, University of Stuttgart

Hammel JU, Nickel M (2008) Pardosa hyperborea (Araneae: Lycosidae): a first report from Disko Island (West Greenland), with remarks on the biogeography of the species. Entomol Medd 76:41-47

Howes BJ, Lougheed SC (2007) Male body size varies with latitude in a temperate lizard. Can J Zool 85:626-633

- Høye TT, Forchhammer MC (2008) Phenology of high-arctic arthropods: effects of climate on spatial, seasonal and inter-annual variation. Adv Ecol Res 40:299-324

Høye TT, Post E, Meltofte H, Schmidt NM, Forchhammer MC (2007) Rapid advancement of spring in the High Arctic. Curr Biol 17:R449-R451

> Høye TT, Hammel JU, Fuchs T, Toft S (2009) Climate change and sexual size dimorphism in an arctic spider. Biol Lett 5:542-544

Isaac JL (2005) Potential causes and life-history consequences of sexual size dimorphism in mammals. Mammal Rev 35: $101-115$

Karl I, Fischer K (2008) Why get big in the cold? Towards a solution to a life-history puzzle. Oecologia 155:215-225

Larsen S, Scharff N (2003) The spiders of Greenland-a checklist. Entomol Medd 71:53-61

> Lensing JR, Wise DH (2006) Predicted climate change alters the indirect effect of predators on an ecosystem process. Proc Natl Acad Sci USA 103:15502-15505

Meltofte H, Høye TT, Schmidt NM (2008) Effects of food availability, snow and predation on breeding performance of waders at Zackenberg. Adv Ecol Res 40:325-343 
Millien V, Lyons SK, Olson L, Smith FA, Wilson AB, Yom-Tov Y (2006) Ecotypic variation in the context of global climate change: revisiting the rules. Ecol Lett 9:853-869

Mysterud A, Coulson T, Stenseth NC (2002) The role of males in the dynamics of ungulate populations. J Anim Ecol 71: 907-915

Pickavance JR (2001) Life-cycles of four species of Pardosa (Araneae, Lycosidae) from the island of Newfoundland, Canada. J Arachnol 29:367-377

Post E, Forchhammer MC (2008) Climate change reduces reproductive success of an arctic herbivore through trophic mismatch. Philos Trans R Soc Lond B Biol Sci 363: 2369-2375

Post E, Forchhammer MC, Bret-Harte MS, Callaghan TV and others (2009) Ecological dynamics across the Arctic associated with recent climate change. Science 325:1355-1358

Prenter J, Elwood RW, Montgomery WI (1999) Sexual size dimorphism and reproductive investment by female spiders: a comparative analysis. Evolution 53:1987-1994

Rasband WS (2008) ImageJ. U.S. National Institutes of Health, Bethesda, MD

Roff DA (1992) The evolution of life histories - theory and analysis. Chapman \& Hall, New York, NY

Schäuble CS (2004) Variation in body size and sexual dimorphism across geographical and environmental space in the frogs Limnodynastes tasmaniensis and L. peronii. Biol J Linn Soc 82:39-56

Simpson MR (1993) Reproduction in two species of arctic arachnids, Pardosa glacialis and Alopecosa hirtipes. Can J Zool 71:451-457

Simpson MR (1995) Covariation of spider egg and clutch size: the influence of foraging and parental care. Ecology 76: 795-800

Stillwell RC, Fox CW (2007) Environmental effects on sexual size dimorphism of a seed-feeding beetle. Oecologia 153: $273-280$

Stillwell RC, Fox CW (2009) Geographic variation in body size, sexual size dimorphism and fitness components of a seed beetle: local adaptation versus phenotypic plasticity. Oikos 118:703-712

Stillwell RC, Blanckenhorn WU, Teder T, Davidowitz G, Fox CW (2010) Sex differences in phenotypic plasticity affect variation in sexual size dimorphism in insects: from physiology to evolution. Annu Rev Entomol 55:227-245

Teder T, Tammaru T (2005) Sexual size dimorphism within species increases with body size in insects. Oikos 108: 321-334

Trenberth KE, Jones PD, Ambenje P, Bojariu R and others (2007) Observations: surface and atmospheric climate change. In: Solomon S, Qin D, Manning M, Chen Z, Marquis M, Averyt KB, Tignor M, Miller HL (eds) Climate change 2007: the physical science basis. Contribution of Working Group I to the Fourth Assessment Report of the Intergovernmental Panel on Climate Change. Cambridge University Press, Cambridge, NY, p 235-336

Tryjanowski P, Sparks T, Rybacki M, Berger L (2006) Is body size of the water frog Rana esculenta complex responding to climate change? Naturwissenschaften 93:110-113

Tuljapurkar S, Gaillard JM, Coulson T (2009) From stochastic environments to life histories and back. Philos Trans R Soc Lond B Biol Sci 364:1499-1509

Uhl G, Schmitt S, Schäfer MA, Blanckenhorn WU (2004) Food and sex-specific growth strategies in a spider. Evol Ecol Res 6:523-540

> Vertainen L, Alatalo JM, Mappes J, Parri S (2000) Sexual differences in growth strategies of the wolf spider Hygrolycosa rubrofasciata. Evol Ecol 14:595-610

- Wilder SM, Rypstra AL (2008a) Sexual size dimorphism mediates the occurrence of state-dependent sexual cannibalism in a wolf spider. Anim Behav 76:447-454

Wilder SM, Rypstra AL (2008b) Sexual size dimorphism predicts the frequency of sexual cannibalism within and among species of spiders. Am Nat 172:431-440

> Wise DH (2006) Cannibalism, food limitation, intraspecific competition and the regulation of spider populations. Annu Rev Entomol 51:441-465

Appendix 1. Vegetation characteristics at sampling sites

To characterise the habitat around each trap, the vegetation coverage of individual plant species (excluding grasses), total vegetation coverage, coverage of mosses and lichens as a single group and coverage of dead biomass (twigs and litter) were estimated within a $2 \times 2 \mathrm{~m}$ frame centred around the pitfall trap. The exact reference to the sampling sites and altitude is given in Table A1. An overview of the vegetation analysis is presented in Fig. A1, and coverage of dominating and characteristic plant species of each sampling site is presented in Table A2. Around Arktisk Station, the 2 sites S1 and S2 were found to have vascular plants covering about $70 \%$, and mosses and lichens covered 3 to $25 \%$ and $<3 \%$, respectively. At S1, almost no bare ground and only a small amount of twigs and litter were recorded. About $25 \%$ of the investigated area at S2 was bare ground and gravel, and a lot of twigs and litter were recorded between vascular plants. Sites E1 and E3 in Engelskmandshavn showed an almost complete covering with vascular plants and a small amount of mosses. Only a small share of twigs and litter was found. E2 was at a shingle beach with no vegetation cover at all. The Lyngmarksfjeld area has luxuriant vegetation. At higher elevation, heath vegetation is common, but diminishing in coverage with increasing altitude. At around $500 \mathrm{~m}$ a.s.l, the vegetation coverage varies between 40 and $70 \%$, but above $600 \mathrm{~m}$ a.s.l., the vegetation coverage is less than $10 \%$. At the highest point, only isolated plants could be found.
Table A1. Site names, exact coordinates for locations of sites and altitude (m above sea level) for each of the sampling sites

\begin{tabular}{|lccc|}
\hline Site & \multicolumn{2}{c}{ Coordinates } & Altitude \\
\hline E1 & $69^{\circ} 15.575^{\prime} \mathrm{N}$ & $53^{\circ} 33.994^{\prime} \mathrm{W}$ & 0 \\
E2 & $69^{\circ} 15.617^{\prime} \mathrm{N}$ & $53^{\circ} 34.031^{\prime} \mathrm{W}$ & 0 \\
$\mathrm{E} 3$ & $69^{\circ} 15.639^{\prime} \mathrm{N}$ & $53^{\circ} 34.031^{\prime} \mathrm{W}$ & 4 \\
$\mathrm{~S} 1$ & $69^{\circ} 15.275^{\prime} \mathrm{N}$ & $53^{\circ} 30.811^{\prime} \mathrm{W}$ & 5 \\
S2 & $69^{\circ} 15.155^{\prime} \mathrm{N}$ & $53^{\circ} 31.034^{\prime} \mathrm{W}$ & 9 \\
L1 & $69^{\circ} 15.490^{\prime} \mathrm{N}$ & $53^{\circ} 32.759^{\prime} \mathrm{W}$ & 0 \\
$\mathrm{~L} 2$ & $69^{\circ} 15.774^{\prime} \mathrm{N}$ & $53^{\circ} 32.854^{\prime} \mathrm{W}$ & 110 \\
$\mathrm{~L} 3$ & $69^{\circ} 15.946^{\prime} \mathrm{N}$ & $53^{\circ} 33.172^{\prime} \mathrm{W}$ & 190 \\
L4 & $69^{\circ} 16.043^{\prime} \mathrm{N}$ & $53^{\circ} 33.279^{\prime} \mathrm{W}$ & 313 \\
L5 & $69^{\circ} 16.242^{\prime} \mathrm{N}$ & $53^{\circ} 33.815^{\prime} \mathrm{W}$ & 416 \\
L6 & $69^{\circ} 16.407^{\prime} \mathrm{N}$ & $53^{\circ} 33.688^{\prime} \mathrm{W}$ & 522 \\
L7 & $69^{\circ} 16.513^{\prime} \mathrm{N}$ & $53^{\circ} 33.810^{\prime} \mathrm{W}$ & 603 \\
L8 & $69^{\circ} 16.622^{\prime} \mathrm{N}$ & $53^{\circ} 34.205^{\prime} \mathrm{W}$ & 694 \\
L9 & $69^{\circ} 16.944^{\prime} \mathrm{N}$ & $53^{\circ} 34.421^{\prime} \mathrm{W}$ & 796 \\
\hline
\end{tabular}


Appendix 1 (continued)

Table A2. Dominating and characteristic vegetation in the surroundings of the sampling sites. Dominating plant species are indicated by ++ ; less abundant, but characteristic plants for certain sampling sites are marked with +

\begin{tabular}{|c|c|c|c|c|c|c|c|c|c|c|c|c|c|c|}
\hline \multirow[t]{2}{*}{ Plants } & \multirow[b]{2}{*}{ L1 } & \multirow[b]{2}{*}{ L2 } & \multirow[b]{2}{*}{ L3 } & \multirow[b]{2}{*}{$\mathrm{L} 4$} & \multirow[b]{2}{*}{ L5 } & \multirow[b]{2}{*}{ L6 } & \multicolumn{2}{|c|}{ Sampling site } & \multirow[b]{2}{*}{ L9 } & \multirow[b]{2}{*}{$\mathrm{S} 1$} & \multirow[b]{2}{*}{$\mathrm{S} 2$} & \multirow[b]{2}{*}{ E1 } & \multirow[b]{2}{*}{$\mathrm{E} 2$} & \multirow[b]{2}{*}{ E3 } \\
\hline & & & & & & & L7 & L8 & & & & & & \\
\hline Alchemilla glomerulans & & & & & & & & & & & & ++ & & \\
\hline Antennaria canescens & & & & & & + & & & & & & & & \\
\hline Bartsia alpina & & & & & + & & & & & & & ++ & & \\
\hline Betula nana & & ++ & & & + & & & & & & & & & \\
\hline Campanula uniflora & & & & & + & + & & & & & & & & \\
\hline Carex rariflora & & & & & & & & & & & & ++ & & \\
\hline Carex sp. & & & & & & & + & + & & & & & & \\
\hline Cassiope tetragona & & ++ & & & ++ & & & & & & & & & \\
\hline Cerastium alpinum & & & & & & & + & + & & & & & & \\
\hline Chamenaerion latifolium & & & & & & & & & & ++ & & & & \\
\hline Draba glabella & & & & + & & & & & & & & & & \\
\hline Draba nivalis & & & & + & + & & & & & & + & & & \\
\hline Dryas integrifolia & & & ++ & & + & & & & & ++ & & & & \\
\hline Empetrum hermaphroditum & ++ & ++ & & & & & & & & ++ & ++ & ++ & & ++ \\
\hline Equisetum arvense & ++ & & & & & + & & & & ++ & & ++ & & + \\
\hline Juncus arcticus & & & & & & & & & & & & ++ & & \\
\hline Luzula confusa & & & & & & & & & & ++ & & & & \\
\hline Oxyria digyna & & & & & & & + & + & & & & & & \\
\hline Pedicularis flammea & & & & & & & & & & & & & & + \\
\hline Pedicularis hirsuta & ++ & & & & & & & & & & & & & \\
\hline Pedicularis sp. & & & & + & + & + & & & & & & & & \\
\hline Poa alpina & & & & + & + & + & + & + & & & + & & & + \\
\hline Poaceae & & ++ & + & & & & + & + & & ++ & + & ++ & & \\
\hline Polygonum viviparum & & ++ & + & ++ & ++ & ++ & & & & ++ & + & ++ & & ++ \\
\hline Pyrola grandiflora & & ++ & & ++ & ++ & & & & & ++ & ++ & & & ++ \\
\hline Salix glauca & ++ & ++ & ++ & ++ & ++ & ++ & ++ & & & ++ & ++ & ++ & & ++ \\
\hline Salix herbaceae & & & & ++ & & & & & & & & & & \\
\hline Saxifraga caespitosa & & & + & & & + & + & + & & & & & & \\
\hline Saxifraga cernua & & & & & & & + & + & & & & & & \\
\hline Saxifraga nivalis & & & & & & & + & + & & & & & & \\
\hline Saxifraga tenuis & & & & & & & + & + & & & & & & \\
\hline Saxifraga tricuspidata & & & + & + & + & & & & & & + & & & \\
\hline Silene acaulis & & & ++ & + & & + & & & & & & & & \\
\hline Stellaria longipes & & & & + & + & + & + & & & ++ & + & & & + \\
\hline Thalictrum alpinum & & & & & & & & & & & & ++ & & \\
\hline Tofieldia pusilla & ++ & & & & & & & & & & & & & \\
\hline Vaccinium uligonosum & ++ & ++ & ++ & ++ & ++ & & & & & ++ & ++ & & & ++ \\
\hline
\end{tabular}

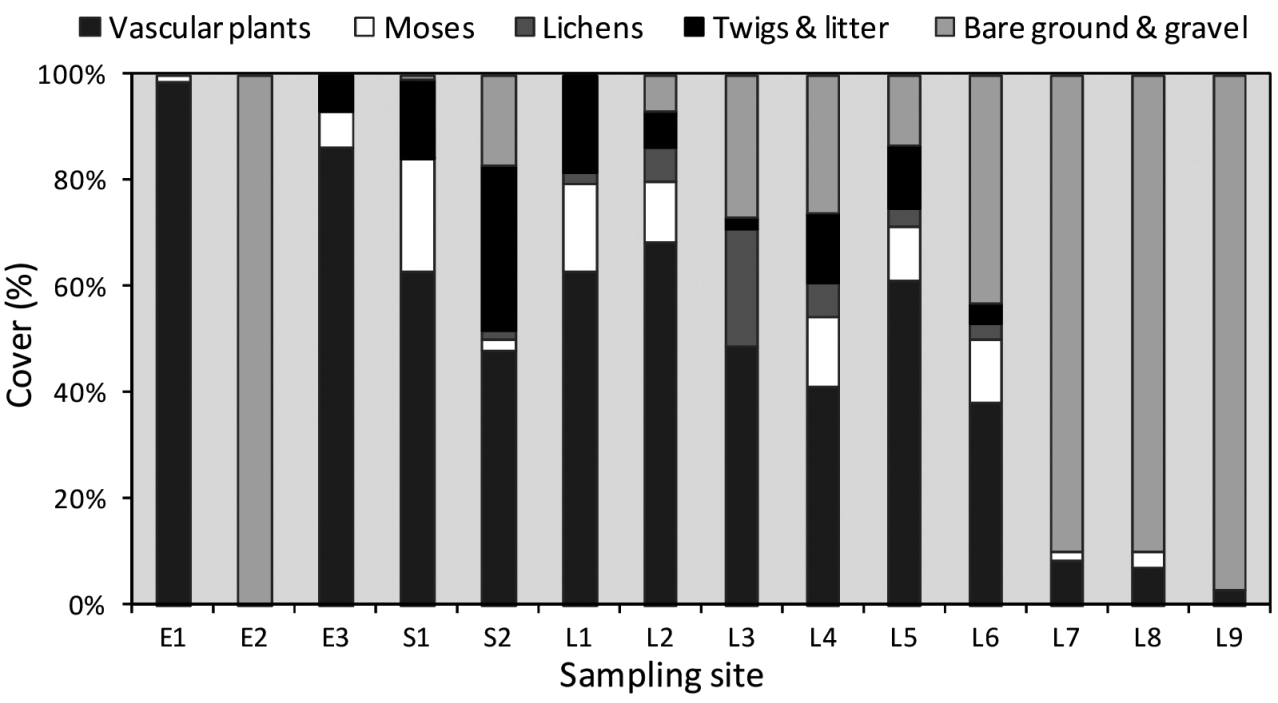

